\title{
COMPLIANCE OF FIRE SAFETY MEASURES FOR ACCOMMODATION OF PEOPLE IN RIGA SCHOOLS
}

\author{
Mihails Urbans ${ }^{1}$, Mg.; Jelena Malahova ${ }^{2}$, Associate professor Dr.oec.; \\ Vladimirs Jemeljanovs ${ }^{3}$, Professor Dr.Sc.Ing. \\ ${ }_{1,2,3}$ Riga Technical University, Latvia
}

\begin{abstract}
This article describes the situation with fire safety at Riga schools regarding their compliance with the fire safety requirements set in Latvia for accommodation of people in schools.

The objective of the current paper was to research and evaluate the compliance with the requirements of regulatory enactments regarding the accommodation in Riga schools and analyse the actual fire safety situation during accommodation of participants of the Dance and Song Festivals in Riga schools.

The research was conducted in spring of 2018, prior to the Dance and Song Festival, assessing the compliance of 60 accommodation sites with the Latvian regulatory enactments on fire safety. During the Dance and Song Festival, it was planned to organise accommodation places in schools for 24000 persons - participants of the festival events in the city of Riga.

Ensuring fire safety at public facilities is a topical issue for any country, since the fulfilment of fire safety requirements is important not only in cases, when school premises are intended to be used for temporary accommodation of participants of the Dance and Song Festivals for a period not exceeding a week, but also in cases when children have to stay in school premises every day to receive the knowledge they will need in their future lives and the fulfilment of fire safety regulations is an important condition for providing the overall safety.
\end{abstract}

Key words: fire safety management, injury prevention, burn, accommodation, deficiencies.

JEL code: R19, L89

\section{Introduction}

The paper faces the problem: the situation with the provision of fire safety measures at shortterm accommodation sites for participants of the Dance and Song Festivals in Riga.

Topicality of the current paper is defined by the research and analysis of the problem regarding the safety of participants of the Dance and Song Festivals that pertains to fire safety measures at places of accommodation during the Dance and Song Festivals. Ensuring fire safety measures is an existing complex issue, as standards are changing and new technologies are developing to make life more comfortable and safer for people. Fire disaster happens to be one of the world's most common and destructive disasters (Pontip Stephen Nimlyat et al., 2017). Life and health of people and participants in organised events depend on the proper functioning of a fire safety system in the event of emergency. In order to reduce this hazard, plenty of requirements and standards have been developed, the timely and correct execution of which allows to reduce the existing hazards to the minimum.

The characteristics of the fire safety systems installed at accommodation sites in Latvia are very different, but in general, an accommodation site must comply with the safety requirements set by the Cabinet Regulation, which are mandatory for all temporary accommodation sites that are not used for permanent accommodation, i.e. all sites not engaged in provision of hotel services.

The subject matter of the research was fulfilment of the requirements of the Cabinet Regulation No. 238 adopted on 19 April 2016 "Fire Safety Regulations" (hereinafter - the Regulation) during the Dance and Song Festivals.

As the research object, 60 accommodation sites in Riga for participants of the Dance and Song Festivals - schools (hereinafter - the educational establishments) were selected.

\footnotetext{
${ }^{1}$ Mihails Urbans e-mail: Mihails.Urbans@riga.Iv

2 Jelena Malahova e-mail: Jelena.Malahova@rtu.Iv

${ }^{3}$ Vladimirs Jemeljanovs e-mail: Vladimirs.Jemeljanovs@rtu.Iv
} 
The objective of the research is: "to perform a research and evaluate the compliance of the accommodation requirements at Riga educational establishments with the regulatory enactments and analyse the actual fire safety situation at the time of accommodation of participants of the Dance and Song Festivals in Riga schools".

To achieve the aforementioned objective, the following tasks have been solved:

1) 60 educational establishments in Riga have been inspected, checking the fire safety situation;

2) the existing deficiencies in provision of fire safety measures have been identified;

3) factors contributing to the deficiencies regarding the overall situation at accommodation sites have been analysed.

The following scientific methods were applied in the study: the analysis - actual fire safety rules were divided into separate points and examined in separate parts concerning appropriateness of the Song Festival accommodation capacity and the fire safety situation; the induction - with the help of this method general judgments and conclusions were made on the individual shortcomings of each educational institution in the background of the survey.

\section{Urgency of the situation}

Major attributes to the poor situation with fire safety in Latvia in the $21^{\text {st }}$ century are still the insufficient funding to ensure the compliance of the fire safety situation with the requirements of the adopted regulatory enactments. Today not only reaction at the time of a fire is of importance, but also prevention measures that do not allow fire to occur. A fire protection system is a prevention and suppression technique adopted in the designing of a building (Kironji Maina, 2014). Educational establishments are places where young people are mostly present in the study process and preventive measures should, therefore, be given special attention. Generally, young people aged 18 to 24 make up a significant proportion of people who are unsafe with regards to fire (Ian Lambie, et al., 2015). In total, as of 1 September 2019, 109 general secondary education institutions, (Education, Youth, and Sports Department of Riga City Council, 2019) where students receive basic and secondary education, were operating in Riga. However, educational establishments in Riga are used not only within the framework of the study process, but also when organising large festivals with a large number of participants involved.

The tradition of the Song festivals, inspired by the protestant culture, has become an integral part of the Baltic States' identity. The Song festivals were created to demonstrate the diversity of heritage and national history (Repsiene, 2016). In 2018, from 30 June to 8 July, the XXVI Latvian Song Festival and the XVI Dance Festival (Latvija 100, 2019) were organised, when 43000 participants from 118 Latvian municipalities, as well as other countries where Latvians support and develop the Song and Dance Festival traditions, arrived to Riga. In Latvia, there are 69,600 amateur artists who take part in different amateur art groups: they dance, sing in choirs, make theatre or come together to knit or weave. They form $3.5 \%$ of the total number of inhabitants in Latvia in 2015. The majority of these amateur artists sustain the tradition of the Nationwide Song and Dance Celebration in Latvia (Tjarve et al., 2017).

During seven days, over 65 events took place - chorus, dance, brass orchestra, kokle (national Latvian musical instrument), folk music, vocal ensemble, folklore group and other concert programmes in Latvian folk attire, exhibitions of applied folk art and amateur theatrical performances. 500000 spectators could attend the festival (during paid and free events) (Nra.lv, 2019). 
One of the important issues in organisation of such festivals is accommodation of its participants. It is well known that the number of the participants is very large and the hotels available in Riga just cannot provide rooms for all, where they could have rest after rehearsals, as well as rooms to spend night. It can be concluded that hotel services are used not only by the festival participants, but also by guests of the city who arrive specially for the Song and Dance Festivals. Therefore, to ensure the accommodation of participants, as a positive practice, educational establishments are used, where the participants relax between rehearsals, get ready for performances and spend nights, so that there is no need to go home because it would take a lot of time. The results of this research are significant to demonstrate the overall fire safety situation to those who are interested, as well as to ensure interest of the responsible institutions to provision of safety in the premises of the educational establishments.

\section{Research of the situation and analysis of deficiencies}

Observation of the Regulation is an important prerequisite for provision of safety measures, as well as "hazards associated with fire outbreaks in buildings need to be addressed efficiently and effectively" (Rahardjo et al., 2020). People spend much of their time in buildings and as such the term fire safety is referred to as preventing fire, restricting the spread of smoke and fire, and extinguishing a fire, and providing quick and safe evacuation (Littlewood et al., 2017).

During inspection of the educational establishments, Table 1 was compiled, reflecting shortcomings in the field of fire safety in each educational establishment, as well as summarising information across all educational establishments and identifying common deficiencies. Table 1 provides in a horizontal row all educational establishments included in the research, where participants of the Dance and Song Festivals were accommodated. The vertical column provides Articles of the Regulation within the framework of which the research has been performed. For each case of revealing an actual non-compliance with the Regulation, 1 point is awarded in the Table. When an educational establishment has several buildings and each of them has similar deficiencies, the points are summed up; for example, if there two buildings, both with similar deficiencies, the digit 2 will appear in the Table. When the premises and fire safety measures there comply with the requirements of the Regulations, this will be indicated with the digit 0 . Thus, the educational establishments that are fully compliant with the requirements of the Regulation have the digit 0 in Table 1, next to the respective Articles. 


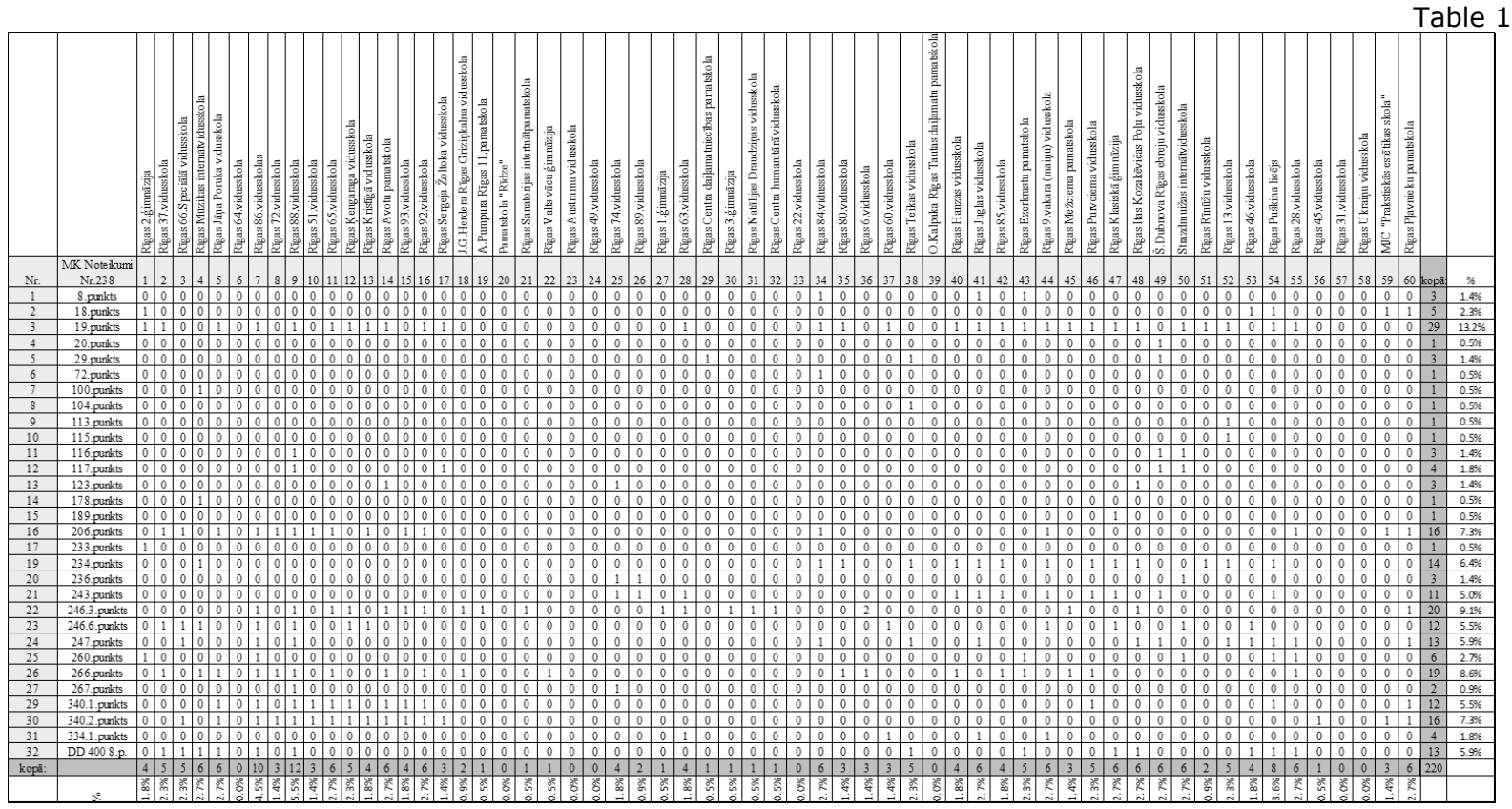

Source: author's calculations based on research information

Table 1 shows in a summarised way, in general, the highest percentage of non-conformities at each educational establishment and the highest deficiencies in compliance with fire safety Articles.

The effective functioning of the fire protection system at educational establishments is achieved by the provision of efficient fire protection measures (active and passive), which include fire doors, fire alarms, the use of separate compartments to limit the spreading of smoke and fire. Therefore, it is important to understand what shortcomings exist and why they have occurred.

The maximum number of deficiencies revealed at a single educational establishment during the research is 12 , while the average number of deficiencies ranged from 4-6 at a single educational establishment. In general, it has been found that administration of the educational establishments has poor knowledge about the requirements of the Regulation, and, thus, the deficiencies have been identified mainly due to the lack of knowledge about the nature of fire safety and the lack of understanding of the norms.

The largest deficiencies have been revealed in non-compliance with Article 19 of the Regulation, which has been identified at 29 educational establishments. This is due to the fact that administration of the educational establishments, failing to comply with the Regulation, removes doors from corridors that connect separate compartments, enclosures and stairways, thereby increasing the possibility of smoke and flame spreading through the whole building of the educational establishment in case of fire. Such type of deficiencies, in general, form $13.2 \%$ out of all or $48.33 \%$ of all educational establishments have such deficiencies. Administration of the educational establishments explained that the doors were removed because pupils, when moving around, do not hold the doors when closing them, so the doors are banging all the time and this disturbs the learning process, as well as the doors get out of order quickly due to this. It has been concluded that even when smoke detectors and other safety systems are installed in the educational establishment, but there are deficiencies in connecting separate compartments, the actual evacuation measures are very much encumbered, especially on upper floors and persons are exposed to the danger of inhaling smoke from burning products during an evacuation.

The next deficiency has been established in non-compliance with Article 246.3, i.e. the evacuation door from inside of an educational establishment cannot be opened within three seconds. When an 
evacuation takes place, keys from the doors are not available at once and very often the keys are somewhere far from the evacuation exit. As a result, the evacuation door does not fulfil its functions and persons cannot get out of the building freely. Such type of deficiencies forms $9.1 \%$ out of all or $33.3 \%$ of all educational establishments have such deficiencies. This Article is directly related to Article 243 of the Regulation, which stipulates that doors on evacuation routes must be opened easily from the inside of a premise, without obstacles. It has been identified that there are obstacles in front of the evacuation doors, such as locked bars. Such type of deficiencies has been identified at 11 educational establishments.

The number of deficiencies at each establishment separately is provided in Figure 1.

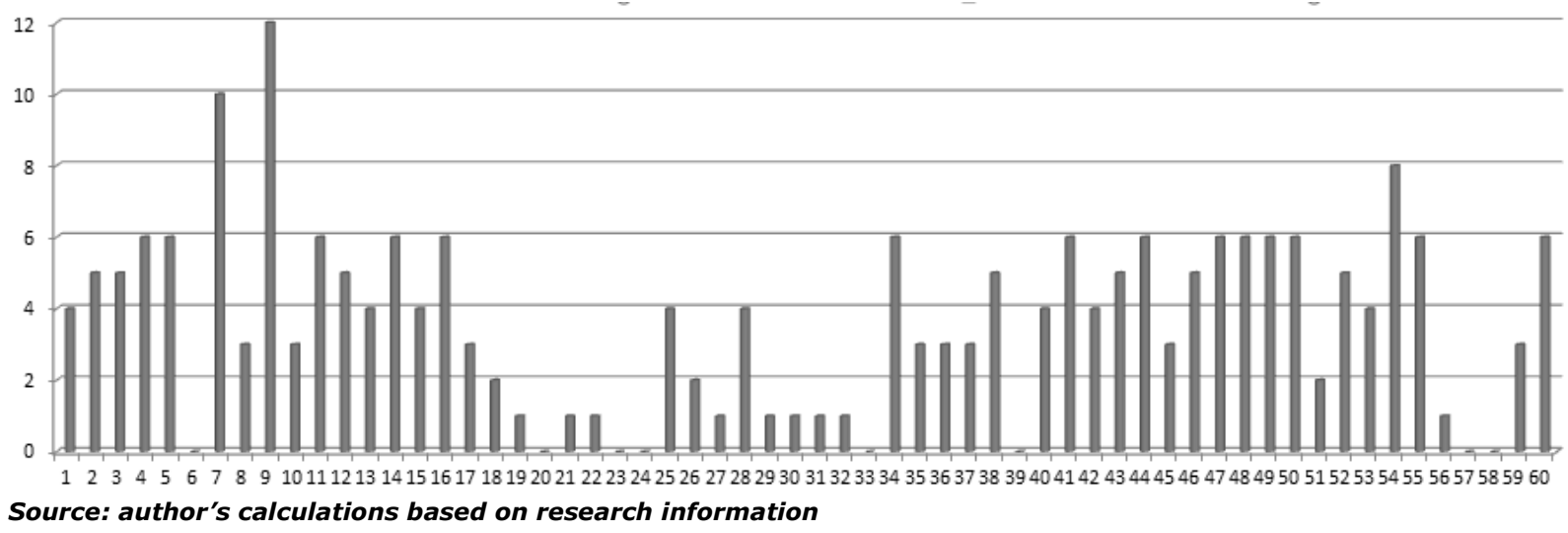

Fig. 1. Number of deficiencies

Deficiencies have also been identified regarding compliance with Article 266, due to the fact that fire extinguishers are not placed appropriately, often too high. The Regulation requires that the height to reach the handle of a fire extinguisher may not exceed 1.5 metres. Administration of the educational establishments explains that, when the devices are placed in accordance with the requirements of the Regulation, children often play with them during breaks and several times they have been activated. Such type of deficiencies has been revealed at 19 educational establishments and form $8.6 \%$ out of all or $31.3 \%$ of all educational establishments have such deficiencies.

There are also deficiencies identified regarding compliance with Articles 206 and 340.2, due to the fact that premises of the educational establishments were mostly built during the period from 1950 to 1990 and systems with escape exit lighting and voice notification were not available at that time. The deficiencies regarding both Articles have been identified 16 times. Still, it must be positively noted that administrations of the educational establishments nevertheless install such systems by using their own budgets, but the process does not go on very quickly. In total, the failure to comply with these Articles has been established at $14.6 \%$ of all educational establishments.

Deficiencies have also been identified regarding compliance with Article 234, due to the fact that evacuation exits, placement of fire extinguishers differ from what is provided in the evacuation plans. Such type of deficiencies indicates to poor fire safety management at educational establishments deficiencies have been revealed at 14 educational establishments and form $6.4 \%$ out of all. It is important to note that the emergency plan should include emergency disposal measures after the fire, emergency rescue operations, rescue equipment and supplies to protect, post disaster relief and resettlement of personnel and a series of related issues as the operation of the steps (Meng et al., 2016).

Deficiencies have also been identified regarding compliance with Article 247, due to the fact that distances to fire extinguishers have been incorrectly estimated, or their number does not comply 
with the requirements of the Regulation, there are not enough extinguishers, although their capacity is higher than required. This deficiency is mostly caused by poor knowledge of the administration how to calculate the required amount of fire extinguishers at the educational establishment. Such type of deficiencies has been revealed at 13 educational establishments and in total constitutes $5.9 \%$ of all deficiencies. Similar number of deficiencies have also been identified in the field of occupational safety, which is closely linked to fire safety measures. Administration of the educational establishments has not identified the site for assembling of employees and pupils in the event of an evacuation.

Deficiencies have also been identified regarding compliance with Articles 246.6 and 340.1. The first Article prohibits changing of the door opening direction without complying with the requirements laid down in the construction standards, while the second Article provides that a facility, which is not intended for accommodation of people at night, may provide it, on condition an automatic fire detection and alarm system is installed at the facility - this has not been done due to the installation costs. Non-compliance with both requirements has been revealed at 12 educational establishments and forms $5.5 \%$ each out of the total number of deficiencies. Fire detection system is an important component in surveillance systems. Fire sensors are, in fact, complementary to conventional point sensors (e.g. smoke and heat detectors), which provide people the early warnings of fire occurrences (Bu et al., 2019). Installation of such systems is particularly important for educational establishments, where there are plenty of people, mostly children, and it must be concluded that the failure to provide such systems when participants of the Song and Dance Festivals are accommodated is unacceptable and increases the hazard considerably.

Deficiencies have also been identified regarding compliance with Article 260, due to the fact that canteens that provide food are not equipped with flame retardant mats. This is mostly caused by the fact that the previous Regulation did not contain such requirements and the administration do not know that flame retardant mats are required. Hence, the explanation is that the administration does not follow changes in regulatory enactments.

Having considered all deficiencies, it has been established that only eight educational establishments have completely fulfilled the requirements of the Regulations, so participants of the Song and Dance Festivals can be accommodated there, as well as nine educational establishments have just one deficiency, which can be eliminated fast, if funds are allocated to improve their fire safety systems. In total, only 17 out of 60 educational establishments can be used during the Song and Dance Festivals, provided a part of them makes immediate improvements of their fire safety systems and elimination of deficiencies.

Other deficiencies do not have a systemic character and it can be stated that they are mainly related to the perfunctory attitude of the administration of educational establishments. In general, the main factors for the fire safety deficiencies are non-compliance with the provisions of the Regulation, due to general shortcomings in the common preventive safety system, which are related to the lack of funds, negligence, inappropriate or damaged components of the safety system that constitute the general safety system of an educational establishment. A situation is made possible, when smoke can quickly spread across the entire educational establishment, preventing safe evacuation of people. It must be concluded that the State Fire and Rescue Service, which controls educational establishments, is not capable of influencing the administration of educational establishments, the actual fines are not imposed when writing safeguards, since the effective 
provision of fire safety measures requires funds that are not allocated to the budget institutions in the required amount.

\section{Conclusions}

The authors carried out a study and assessed the accommodation facilities of Riga general education institutions, as well as established their shortcomings and deficiencies, which allows to judge on the lack of full preparedness of the institutions for the accommodation of participants of the Song and Dance Festival.

As a result of the research, the general compliance of the fire safety system at educational establishments has been determined. 60 general education establishments in Riga, which are intended for accommodation of participants of the Song and Dance Festivals, have been inspected, where the fire safety satiation has been studied. Existing deficiencies in the provision of fire safety measures have been identified. An analysis of the overall situation at the places of accommodation has been performed. The current research established that any further delay on the part of the administration of educational establishments may endanger the lives of people who are accommodated in such premises. This is an initial research, with a limited number of facilities - as a result, the general data on educational establishments of the city of Riga may differ. The results have revealed the need to improve fire safety measures that have not been provided by the administration of educational establishments and that, in view of the established deficiencies, accommodation of people during the Song and Dance Festivals is inadmissible at most of the educational establishments and may result in a wide-scale tragedy. Ensuring fire safety requirements does not mean that the fires have been fully eliminated at educational establishments that observe the Regulation, but fires are reduced to the minimum, in order to maximally protect human lives and property of educational establishments.

\section{Bibliography}

1. Bu, F., Gharajeh, M.S. (2019). Intelligent and Vision-Based Fire Detection Systems: a Survey. Image and Vision Computing Volume 91. Article 103803.

2. Dziesmu svētki 2018. Nra.Iv (2019) Retrieved: https://nra.Iv/temas/123-dziesmu-svetki-2018.htm. Access: 15.11.2019.

3. Education, Youth, and Sports Department of Riga City Council. Retrieved: https://katalogsiksd.riga.lv/lv/izglitibas-iestades/skolas/filterinst/all. Access: 15.10.2019.

4. Kironji, M. (2014). Evaluation of Fire Protection Systems in Commercial Highrise Buildings for Fire Safety Optimization A Case of Nairobi Central Business District. International Journal of Scientific and Research Publications Volume 5, Issue 1: pp. 2250-3153.

5. Lambie, I., Best, C., Tran, H., Ioane, J., Shepher, M. (2015). Risk Factors for Fire Injury in School Leavers: A Review of the Literature Fire Safety Journal Volume 77, pp.59-66.

6. Latvija 100. (2019). Retrieved: https://www.Iv100.Iv/programma/kalendars/visparejie-latviesu-dziesmu-unxvi-deju-svetki-2018/. Access: 01.11.2019.

7. Littlewood, J. R, Alam, M., Goodhew, S., Davies, G. (2017). The 'Safety Gap' in Buildings: Perceptions of Welsh Fire Safety Professionals, ScienceDirect, Energy Procedia Volume 134. pp. 787-796.

8. Meng, D., Yao, H., Cui, T., Sun, Y. (2016). Survey and Countermeasure Discussion of College students' Campus Fire Safety. Procedia Engineering. Volume 135. pp. $25-28$.

9. Nimlyat, P.S., Audu, A.U., Ola-Adisa, E.O., Gwatau, D. (2017). An Evaluation of Fire Safety Measures in Highrise Buildings in Nigeria. Sustainable Cities and Society. Volume 35, pp.774-785

10. Rahardjo, H.A., Prihanton, M. (2020). The Most Critical Issues and Challenges of Fire Safety for Building Sustainability in Jakarta, Journal of Building Engineering Volume 29. Article 101133.

11. Repsiene, R. (2016). The Song Celebration as Power of Cultural Memory and a Mission of Modernity. Journal Culture Crossroads Nr.1. pp.20-35.

12. Tjarve, B., Zemite, I., Freiberga, K. (2017). Fiscal Decentralisation in Amateur Art Sector in Latvia: Case of Song and Dance Celebration. TRAMES. Volume 21(71/66), Issue 4, pp. 383-402. 